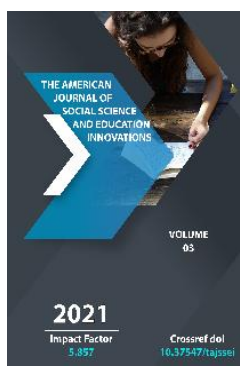

\title{
Invariant And Variant In Interesting Marriage Motivation
}

Dilobar Abdujalil Kizi Azizova

Master Student Of Andizhan State University, Andizhan Region, Republic Of Uzbekistan

Journal Website:

https://theamericanjou

rnals.com/index.php/ta

jssei

Copyright: Original content from this work may be used under the terms of the creative commons attributes 4.0 licence.

\section{ABSTRACT}

The article analyzes the theory of motives, the motives of marriage in Uzbek literature and the concept of variant and invariant in it, plot motives and their poetic features. In proving his views and conclusions, reference was made to works of art belonging to the literature of the 1920 s and 1930 .

\section{KEYWORDS}

Motive, Plot Scheme, Invariant And Variant, Motive Subject And Object, Formal And Semantic Components Of Motive.

\section{INTRODUCTION}

As Veselovsky puts it, motif is the smallest unit of a plot that has a certain stability, that cannot be divided into other parts [1, p.10]. Issues such as the relationship of motive and plot, motive and character, fable and motive, immutability and variability of motive have been studied specifically in world literature, especially in Russian literature. Veselovsky emphasizes the inseparability of the motive. In his view, motives are universal realities that move from work to work. In the following period, views on the occurrence of certain changes, invariant and variant, in addition to stagnation in motive poetics, emerged. In particular, the literary critic Tomarchenko explains the invariable form of the motif by connecting it with variants, that is, with different motifs in the text of the work [1, p.48]. Beletsky explores Tomarchenko's diachronic motive theory in more detail in his research. Beletsky divided the motive into two types - schematic motive and real motive [1, p.30]. He considers the "real 
motive" as an element of the plot composition of the work, and the "schematic motive" as an unchanging plot scheme, an event outside the plot of the work.

\section{RESEARCH METHODS}

The purposeful marriage of two young people is a "plot scheme" of beneficial marriage, which does not exist in the composition of any work of art, and it lives as the "core of the motive" - the invariant, the possibility of social consciousness. The interest of the parents in the marriage of Otabek and Zaynab turns from a schematic motive to a "real plot" variant with the creative intention of the writer. The fixed motive, which serves as the basis, forms the basis of the motive in the work of art, which is changed by the author's intention. At the same time, social life, worldview, creative personality as a result of "influence" in the broadest sense, "changed constructions" enrich the "plot scheme" in terms of form and content. The stability of the motive, its variable components, and the examination of the factors that give rise to it allow a comprehensive understanding of the dual nature of motive poetics.

\section{RESULTS AND DISCUSSIONS}

The motif enters into a hierarchical relationship with the archetypal scheme (nightingale flower - calligraphy [3.B.112]) (Otabek - Kumush - Homid, or Otabek - Kumush - Zaynab, Zebi Olmasjon - Akbarali, Yulchi - Gulnor Mirzakarimboy and others). The third weighty image among the lovers enters through a beneficial marriage.

The analyzed plot scheme - beneficial marriage is one of the most widely used motives in Uzbek literature. First of all, it is necessary to clarify the term of a beneficial marriage motive. A mutually beneficial marriage is a marriage that is not based on love, but on the basis of a common interest. differs in the observation of cases of regret. In The Scorpion from the Altar, the marriage of Khudoyorkhan and Rana is canceled because of Rana's "brave girl”, and in "It's Hard to Be a Man", the marriage between Abdullah and Sayyora fails because of Gulchehra's death. Or the relationship between Clyde Griffith and in the Tragedy of America and Julien Sorel and Matilda in The Red and Black, one of the most mature works of world literature, does not end with marriage. In some of these and similar novels, marriage does not take place even if the interests pursued by the protagonist (s) exacerbate the conflict and ensure the development of the plot. There is always a choice in front of the subject of the motive, and the main feature of the motive of a beneficial marriage is the preference of interest over two ways - interest or love, the motive is the culmination of the existing plot. That is, in this case, the choice of the protagonist performs an artistic-aesthetic function, not whether the marriage takes place or not in the course of events. The protagonist's renunciation of love, degradation as a person, betrayal and the consequences that follow these novels in terms of the same problem with marriage novels such as "Last Days", "Commemorative Blood”, “Night”, “Sarob”, “Hope”. bring each other closer. Accordingly, although the choice of protagonist in the plot is clear, we consider it appropriate to study and evaluate works that did not take place as marriages as objects of beneficial marriage motives.

From ancient times the people wanted to live rich and prosperous. While being a merchant, or being the groom (bride) of a rich house, is an easy and acceptable option to earn money and prestige, the second is that intentionally marrying a rich wife (or marrying a rich man) is seen in fiction as immoral, contrary to the ideal. In folklore, especially in fairy tales and epics, the protagonist never gives up his love and honor for the sake of gain, but rather rejects it, 
standing one step above material gain. (In the fairy tale "Malikayi Husnobod" the princess does not accept the offer of the princes and marries a poor young man, or in the epic "Alpomish" Toychikhan's daughter does not accept the offer for the sake of Alpomish's honor). Spiritual flaws are alien to the protagonist's character traits, and the second in the fairy tale - the pole of evil - is interpreted as proponents of a beneficial marriage. For example, the old woman in the fairy tale "Yoriltosh" tries to take her stepdaughter to her son. In both of his novels, Abdulla Qadiri was influenced by folklore and made extensive use of image and plot motifs. Although the novels "Last Days" and "Scorpion from the Altar" have a beneficial marriage motif, ideal characters are chosen as the protagonists, as in the examples of folklore. The artist pays special attention to the theme of "love". [6. p.175]. For this reason motive poetics differs significantly from existing works in the same motif created in western literature; the people approach the interpretation in oral creation.

According to the concept of valence, which is widely used in linguistics, words must be compatible not only in form but also in content. The rule of valence is also strictly followed in fiction. In particular, the motive of "insane love" - to love the environment, society, the world to the point of forgetting the insane - is not equivalent to the motive of a beneficial marriage. That is, in a beneficial marriage, the interest for the protagonist is greater than love, he gives up half of it for wealth, career, which is completely contrary to the motive of insane love. In novels such as "Last Days", "Scorpion from the Altar", "Commemorative Blood", the image of love is filled with romantic pathos. Although there is a "crazy love" in the nature of the protagonists, the author follows the path of realistic imagery in his interpretation. In spite of the difficulties and trials in folklore and epics, if in the end the lovers live a happy life, in the novels listed above, the protagonist's attempt to overcome the obstacle is ineffective and a beneficial marriage becomes a barrier between the lovers. In particular, a beneficial marriage (marriage of Otabek and Zaynab) formed under parental pressure leads to a two-year separation between Otabek and Kumush. Or in “Kutlug Kan” Mirzakarimboy and Gulnor's marriage resulted in the death of two young people.

Obviously, the motive is the most important component that develops the plot, through which the course of events moves towards the solution. One motif is interrelated in form and content to another motif. "Motivation involves the potential for growth and is complicated by side motives" [1. p.21]. A combination of plot motifs can be classified as follows in a bar with works with a beneficial marriage motif:
A. The motive of the meeting (the emergence of sincere love between a boy and a girl)
B. Motive of infidelity (cause of rich guy (girl))
C. Motive of Marriage
D. Motive of regret

The motive that comes first in the play also partially determines how the motive that comes after it is understood, analyzed, and evaluated. For example, in the novels "Last Days", "Scorpion from the Altar", "Kutlug Kan" a comprehensive description of the motive of the meeting, the meaning of which is understood: marriage (marriage) is interpreted as a barrier for lovers, a tragedy. The novel "Yesterday" emphasizes the motive of the meeting, that marriage (infidelity) is no longer a tragedy for lovers. When we say the motive of the meeting, we mean the event from when the heroes meet each other to when love develops between the two and the relationship reaches a high level. For this reason, the motive of love also belongs to this nest in content. 
Depending on the execution of the artistic intention, the writer describes one motif more broadly, another more briefly, expands the content, or vice versa. In the novels of Kadyri and Oybek, the high weight of epic elements in the plot allows for a detailed coverage of the meeting motif. ... Of course, "Love Story" was a tool for artistic interpretation of other problems in the novel, but it is undoubtedly of great artistic and aesthetic importance (it is no coincidence that the work was published in one of the foreign languages under the name “Tashkent Lovers"). Fifteen years later, Night and Day has almost no love history; In the novels "Sarob" and "Kutlug Kan" it is obvious that "love story" is a tool. [6. p.175] In the early chapters of Cholpon's novel, little emphasis is placed on the motive of encounter because of the leadership of the dramatic image.

Professor D. Kuronov Cholpon writes that "in the first chapters of" Yesterday "the intensity of the development of the plot is obvious in comparison with The Scorpion from the Altar" [4. p.243] "... At the beginning of the novel, if the dramatic plot develops rapidly, the epic coverage increases as it is inward, the compositional time expands, and the narrative time lengthens" [4.p.244 ]. The expansion of the epic scope envisaged by the scholar relates to the course of events following Zebi's marriage to Commander Akbarali. In the novel "Scorpion from the Altar" (also in "Last Days", "Memorial Blood"), the author "... slows down the plot and pushes its main knot to the 45th chapter of the novel, called" Fatiha - the seal of God. "Indeed, from this point on, the dramatic plot develops very rapidly, gaining a real priority in the structure of the novel"[4. p.244] Later, in Chapter 45, entitled "The Seal of Blessing is God," the dramatic plot of the play develops rapidly, and the image of the motives of betrayal, marriage, and regret is condensed. In "Yesterday", on the contrary, the motives of meeting and infidelity intensify, and the motive of marriage (marriage) is covered in more detail. In the novel "Yesterday", the fact that the meeting is not so significant in terms of the role of the performer in the plot becomes an artistic tool used to promote a certain idea of the creator. That is, the period and environment described by Cholpon are such that in these conditions there is no place for true human feelings. The two young people do not have time to strengthen their relationship and obey the people who are "above" them, accepting the separation (more in Zebi's image, but it is clear that Olmasjon did not fight for his love) as an event that can happen in everyday life. A brief description of the motive of the meeting will also cause the image of the wedding, subsequent events and the content in it to be embossed. In The Last Days, the motive of the meeting is a detailed description of the love between a young man and a young woman. the intensity of the conflict with the environment (parents, father-in-law), and ultimately contributes to the emergence of tragic pathos

The motive for a beneficial marriage requires a situation of expectation of benefits from the marriage, the subject and object of interest. The subject and object of the motif are interpreted in different variants in each play. In the 1920 s and 1930s, when a father, mother, or other character was considered interested in marriage, in novels created relatively later, the subject moved to the image of a married young man.

There are a number of objective reasons why a subject of interest may be a parent, mother, or other person. In particular, the main factor stems from the fact that the creator aims to accurately depict the image of the period. In the novels "Last Days", "Scorpion from the Altar" the khan's time, the period before the Russian invasion, in the novels "Commemorative Blood", "Night" the period 
before the 1917 overturning are written. Given that marriage (especially marriage) was not decided by a boy or a girl during both the khanate and the pre-revolutionary period, given that parental role played a decisive role, whether beneficial or not, almost all marriages were performed by a parent. Second, the love of the protagonists in the above works is "mad love" (except for "Yesterday"). Therefore, the pursuit of a beneficial marriage does not fit into their character logic.

In the novel "Last Days", the dream of the parents is the main factor that creates the marriage, the struggle between the old and the new, reveals the conflict of the heroic environment. Through a profitable marriage, the parents criticize their dreams as a creative ugly environment, a product of old traditions as a value that stifles human freedom, dignity, love, and condemns the individual to unhappiness.

While the motive for marriage in "Last Days" is the result of domestic life and parental desire, in "The Scorpion from the Altar" the motive is selfishness, the humiliation of the clergy, and the actions of the khan and his officials against the just. One of the subjects of interest, Abdurahman, is one of the negative heroes, and the issue of the scholar's human feeling is covered in this image. Abdurahman and his henchmen devise a plan to bring Rano to the khan (beneficial marriage), which was conceived to remove Anwar from the lordship. In the novel "Yesterday", Pashshahon seeks to destroy his cousin Sultankhan and get married in order to reduce his mental torture". In other words, the cause-and-effect relationship is predominant [ $4.248 \mathrm{p}$ ].

Since the class struggle is one of the main themes in the Memorial Blood, marriage is the result of the lowliness of the rich and the shortness of the hands of the poor. It seems that in the first novels of Uzbek prose, the subjects of interest are not the young man (girl) to be married, and therefore marriage (marriage) also includes the content of infidelity. That is, heroes who struggle with devotion to love involuntarily betray love under the influence of an external (subject of interest). The commission of involuntary infidelity causes the motives of infidelity and marriage (marriage) to merge in content. In "Sarob" the change of the subject of interest allowed to separate the motives of infidelity and marriage. The motive for a beneficial marriage changes in content from this very novel. The subject of interest is changed to the groom - Saidi, the bride - Muniskhan. The protagonists of the work voluntarily renounce their love without any external pressure. In this respect, the protagonists of the novel "Sarob" are reminiscent of the characters in the novels "Red and Black" and "American Tragedy', examples of Western literature.

\section{CONCLUSION}

In conclusion, the study of the motive and its poetic features in the historical aspect allows to scientifically substantiate the roots of the events in the literature of the period, the factors that led to the change. The study of variants of the motive of beneficial marriage in the Uzbek literature using the comparativetypological method in the study of general aesthetic problems such as the creative personality, worldview, trends, the impact of the prevailing socio-political environment on the work of art. elements are crucial in finding solutions to purely literary problems. The general and specific points in the novels "Last Days", "Scorpion from the Altar", "Night and Day", "Commemorative Blood" serve as material to prove the above. 


\section{REFERENCES}

1. Silanteev I.V. Poetics of the motive of Yazik Slavyanskaya Kulturi Moscow 2014. - p. 296.

2. Izzat Sultan. Literary theory. -Tashkent: "Ukituvchi" publishing house, 2005. -p. 272.

3. Quronov D. Fundamentals of Literary Studies. -Tashkent: Akademnashr, 2018. p. 480.

4. Quronov D. Poetics of Cholpon's prose. Tashkent: Shark Publishing House, 2004. p. 288.

5. Quronov D, Mamajonov Z, Sheralieva M. Dictionary of Literary Studies.- Tashkent: Akademnashr 2013. p. 408.

6. Quronov D. Reading and comprehension exercises. - Tashkent: Akademnashr, 2013. p. 175 .

7. Abdulla Qadiri. Past Days. - Tashkent: Uzbekistan. 2014. p. 189.

8. Abdulla Qadiri. The Scorpion from the Altar: A Novel, A Century-Old Works. Tashkent: Shark, 2013. p. 288.

9. Cholpon. Night and day. Cholpon works. 4 volumes. Volume 2 - Tashkent: Akademnashr, 2012. p. 352.

10. Oybek. Commemorative blood. Chrestomathy of school literature Tashkent: G. Gulom Publishing House. 2015. p. 396.

11. Abdulla Qahhor. Sarob. - Tashkent: Shark, 1995. p. 240. 